\title{
Shaping our future: animal health in a global trading environment
}

Simon J. More

Centre for Veterinary Epidemiology and Risk Analysis, UCD Agriculture, Food Science and Veterinary Medicine, University College Dublin, Belfield, Dublin 4, Ireland

Key words: animal, health, global, trade, agriculture

Irish Veterinary Journal Volume 60 Number 9, 540-545, 2007

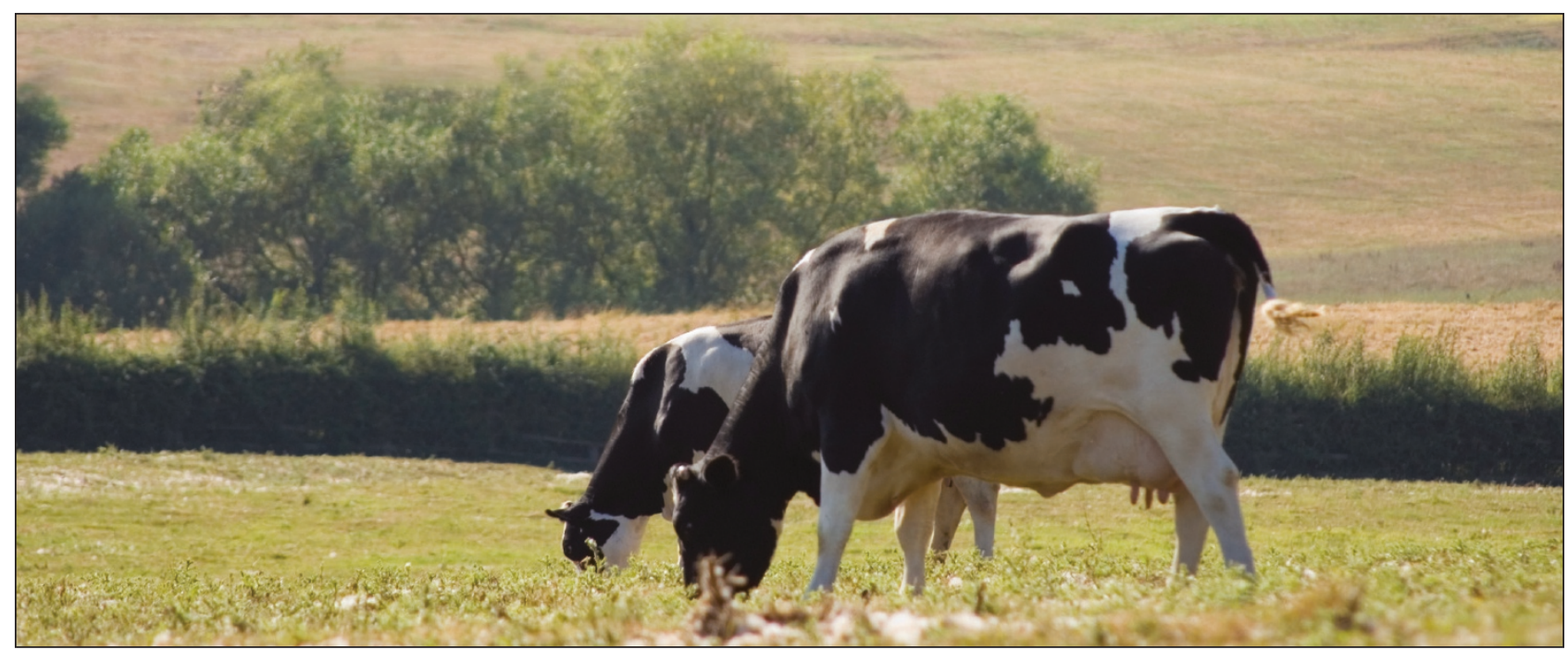

Ireland is currently experiencing both the positive and negative effects of global trade in agricultural products. With increasing global competition, there is little doubt that Irish agricultural product must increasingly compete on the basis of quality, rather than price.

\section{Introduction}

Irish farming is facing a period of unprecedented change, in large part due to the increasing globalisation of agriculture. The challenges to Irish farming are substantial, given ongoing reductions in farm-gate returns to Irish farmers, as a consequence of increasing international competition, decreasing levels of subsidy support as a result of international (WTO) and EU-level decisions and a rapid increase in the relative cost of production of Irish product.

The long-term viability of Irish agriculture is dependent on the ability of industry to maximise on-farm profitability, and to effectively compete in a global trading environment. In terms of the latter, competitiveness is closely linked with cost and value. Although industry and key service providers have as yet mainly focused on efforts to reduce costs, Ireland cannot hope to match key competitors (such as Brazil) on price alone. Logically, therefore, product quality and safety will become increasingly important to the survival of Irish agriculture. Animal health is an important contributor to product quality and safety, in the context of the international competitiveness of Irish agricultural product, as a result of the impact (perceived or otherwise) of animal disease on product quality and because of the special importance of animal health in international trade. To remain viable in coming years, there seems to be little doubt that Irish agriculture will need to focus on one key issue, namely: "What needs to be done to maximise the international competitiveness of Irish agricultural product?"

This paper is based on a presentation to the Animal and Plant Health Annual Conference in Killenard on September 12, 2006. It seeks to address three related questions relevant to current challenges facing livestock production in Ireland, including:

- Is Ireland achieving international best-practice in key areas of animal health?

- If not, does it matter?

- What can we learn from experiences elsewhere?

\section{Is Ireland achieving international best-practice in key areas of animal health?}

There are two broad categories of animal disease/animal health, including:

- Those diseases where 'biosecurity' is important (in broad terms, this would include diseases such as brucellosis or Johne's disease which would be of concern to those who neighbour or purchase from infected farms, as well as the 
infected farm itself); and

- Those diseases where 'biosecurity' is generally not a concern, such as mastitis or lameness.

Of the biosecure diseases, some are currently under government control in Ireland (such as tuberculosis, brucellosis, BSE), whereas others (IBR, BVD, Johne's disease) are not.

\section{i. Biosecure disease (under government control)}

Tuberculosis and brucellosis have been eradicated from a number of countries, including those in northern EU countries (Reviriego Gordejo and Vermeersch, 2006) and Australia (Radunz, 2006). Although there has been very good progress in brucellosis control in Ireland, eradication will not be possible, however, until both Ireland and Northern Ireland have each achieved disease freedom. Whilst some progress with regard to tuberculosis control is being made, progress towards eradication remains problematic; approximately $5 \%$ of Irish herds are newly restricted each year following the detection of one or more reactor animals. There is conclusive evidence that wildlife are a key constraint to eradication in Ireland (Griffin et al., 2005); similar problems are faced in New Zealand (Ryan et al., 2006) and the UK (Reynolds, 2006) and to a lesser extent in the US (O'Brien et al., 2006) and Canada (Nishi et al., 2006). Therefore, control of infection in wildlife is recognised as critical to the success of national eradication programmes in each of these countries, and Ireland is leading international research efforts in this area (More and Good, 2006). Although Ireland has had the second highest number of recorded cases of BSE (1,552 cases to the end of 2005; approximately $9 \%$ of the number recorded in the UK during the same period), there has been a rapid downward trend in cases in recent years, highlighting the effectiveness of Ireland's BSE controls.

\section{ii. Biosecure diseases (not under government control)} Ireland has no formal programmes in place to control IBR, BVD, Johne's disease, however, a range of vaccines are available (for diseases including IBR, BVD, leptospirosis and salmonellosis) to assist with disease control. The Irish chicken industry, through the Egg Quality Assurance Scheme, is leading international efforts towards salmonella control (Anon., 2001a).

Formal programmes to control IBR, BVD and Johne's disease have been in place in a number of European and other countries since at least 1979. IBR has now been eradicated from Norway, Switzerland, Austria, Denmark, Finland, Sweden and regions of Italy, and there is an active control programme in Germany (Anon., 2005a). A number of countries are also approaching BVD-freedom, including Norway, Sweden, Denmark and Finland (Lindberg et al., 2006). Although progress in Johne's disease control has proved more problematic, nationally coordinated programmes are now in place in several countries, including the Netherlands and Australia.

\section{iii. Non-biosecure diseases}

To this point, there has only been limited coordination in Ireland to tackle mastitis, fertility and lameness. The bulk somatic cell counts (SCC) fell between 1994 to 2000, but have subsequently risen (Berry et al., 2006), and many dairy farmers are currently facing significant problems with high somatic cell counts (Kennedy, 2006). In 2004, the bulk SCC geometric mean in Ireland was 250,937 cells/ml (Berry et al., 2006). Based on the 6,045 Irish herds that milk recorded during 2005, 20.7\% of monthly recordings exceeded 400,000 cells/ml (More, unpublished).

In several countries, national programmes have been developed and implemented, resulting in a dramatic and sustained drop in cell counts. In the Scandinavian countries, there has been a progressive drop in cell counts over the last 10-15 years; in Norway, for example, the herd average SCC is now less than 150,000 cells $/ \mathrm{ml}$. In Australia, a national mastitis and cell count control programme (Countdown Downunder) was created by Dairy Australia "to help dairy farmers meet new quality standards, improve farm profitability and protect export markets" (Anon., 2001b). In 2003 (five years after establishment), just under $94 \%$ of herds achieved a cell count of less than 400,000 cells/ml (Brightling et al., 2005).

\section{In summary}

In areas of animal health where government is not involved (that is, many biosecure diseases and all non-biosecure diseases), Ireland is not currently achieving international best-practice, either in the adoption of appropriate processes (what is being done) or measured outputs (what is being achieved). In those areas of animal health where government is involved, there has been substantial progress towards eradication of brucellosis and the resolution of the BSE issue. Although progress towards eradication of tuberculosis has been slower, Ireland is leading international efforts towards a practical solution to the problems presented by an infected wildlife reservoir.

\section{If not, does it matter?}

There are three areas where best-practice in animal health is of importance to Ireland, including on-farm profitability, animal welfare and implications for international trade. Only the latter issue, implications for international trade, will be considered in detail here.

\section{Implications for international trade}

Global markets are critically important to Irish agriculture. During 2004, Ireland was the third highest global exporter of butter and cheese (based on actual value, in US dollars), the seventh highest global exporter of beef (fresh, chilled, frozen, based on value) and the twelfth highest global exporter of milk products (apart from butter and cheese) (International Trade Centre UNCTAD/WTO, 2005).

Although a strong beneficiary of the positive benefits of global trade, Irish agriculture has also been hard-hit by adverse effects of globalisation, including falling product 
value, reducing subsidies and increasing production costs. As a consequence, and due to the ongoing liberalisation of international trade, Ireland must increasingly compete with a range of other exporting nations, including those from northern Europe, North America, Australasia and South America. In such an environment (and fundamental to success in any competitive situation), it is critical that Ireland effectively differentiates its product, thereby providing importing countries with a compelling reason to buy Irish (rather than another) product.

In simple terms, exporting countries have the option to differentiate on the basis of price or quality (or perhaps both). As a result of the recent economic boom in this country (the 'Celtic tiger'), however, it will become increasingly difficult for Ireland to compete on price alone. In Ireland, the cost of agricultural production is increasing, resulting in a substantial price differential between Irish product and product from lower-cost (and minimally-subsidised) countries in Australasia and South America. Of some relevance to the cost of production, Ireland was recently ranked the second wealthiest country in the world (Anon., 2006a), with Dublin now the eighth most-expensive capital in which to live (Anon., 2006b). Given this background, I would argue that Ireland has no choice but to focus on the issue of quality, and to differentiate with competing countries on that basis. Similar sentiments have been expressed by the EU Commissioner for Agriculture and Rural Development, Mariann Fischer Boel, who stated that:

- "We need to shift the emphasis of European farming from quantity to quality. Consumers are growing richer, but they will spend more of their money on food only if they are impressed by its taste, its nutritional value, its production method and origin - and its safety." (Wellington, March 6, 2006; Fischer Boel, 2006a); and

- "A large part of the response must be for the Irish to ... (make) their supply chain more efficient, producing to the very highest standards and letting consumers know why Irish product is worth a premium.” (Dublin, May 10, 2006; Fischer Boel, 2006b).

Animal health is critical to the international competitiveness of Irish agricultural product, as a result of the impact (perceived or otherwise) of animal disease on product quality, and because of the special importance of animal health in international trade. The special importance of animal health in international trade will be considered in detail in this article.

There are many examples of the risks associated with the introduction of animal diseases through international trade. A range of damaging fish diseases (including white spot disease in shrimp and Koi herpesvirus infection of farmed common and Koi carp) have been rapidly spread from country to country as a result of the international movement of fish and fish products (Pokorova et al., 2005). Caseous lymphadenitis (O'Doherty et al., 2000) in sheep and infection with Mycoplasma bovis (Healy et al., 1996), bovine digital dermatitis (Mortellaro disease; Bassett et al., 1990) and warble fly infestation (Thornberry, 1976) in cattle were each introduced into Ireland through international trade. Only the latter has been successfully eradicated. The need to minimise these risks is accepted under international rules of trade. Through the SPS (Sanitary and Phyto Sanitary Measures) Agreement, the World Trade Organization has developed 'rules of trade' which specifically seek to protect the animal health status of importing countries, whilst also ensuring that strict health/safety standards are not used as an excuse to protect domestic agricultural producers (World Trade Organization, 2007). With increasing trade liberalisation, action under the SPS Agreement (for example, to protect superior animal health status) has emerged as one of the few non-tariff barriers to trade that will remain legally acceptable. The SPS Agreement remains critically important to international trade, regardless of the final outcome in the Doha negotiations.

Although the role of animal health in intra (EU)-community trade is more complex, there is no doubt that the relative animal health status of Ireland, in comparison with other member states, will become increasingly important. In the live animal trade, for example, trade will be increasingly constrained by the IBR status of the exporting nation. Similarly, Ireland would also face significant challenges if the Commission, as has been discussed recently, were to move towards a system of single EU export certification in the SPS sector (Anon., 2005b).

\section{In summary}

Ireland is currently experiencing both the positive and negative effects of global trade in agricultural products. With increasing global competition, there is little doubt that Irish agricultural product must increasingly compete on the basis of quality, rather than price. Animal health is critical to the international competitiveness of Irish product, both as a result of the impact of animal disease on product quality, and also because of the special importance of animal health in international trade. In terms of the latter, action under the World Trade Organization's SPS Agreement (for example, to protect superior animal health status) has emerged as one of the few non-tariff barriers to trade that will remain legally acceptable. Although the role of animal health in intra (EU)-community trade is more complex, the animal health status of Ireland in comparison with other EU member states is increasingly important. In conclusion, therefore, it does matter that Ireland is not achieving international best-practice in key areas of animal health. This concern is likely to become increasingly important into the future, as globalisation intensifies.

\section{What can we learn from experiences elsewhere?}

A number of countries are currently leading international efforts in animal health, particularly those in northern Europe (the Netherlands and Scandinavian countries) and Australasia (Australia and New Zealand). Much can be gained from the experiences of these countries, and, in particular, reasons for their successes (and failures). The 
following issues and approaches, which have been identified following detailed in-country discussions with relevant organisations and individuals, have been central to efforts towards improved animal health in these countries. These approaches may also be of relevance to Irish agriculture and farmers.

- A focus on continuous improvement. In a globally competitive environment, quality and safety are now relative rather than absolute. In other words, "standing still is no longer enough ...". As discussed previously, animal health is an important contributor to product quality and safety, in part due to the special importance of animal health in international trade. Product specifications will inevitably rise, with ongoing improvements in product quality and safety. In response, there is a focus on continuous improvement in performance at all levels of agriculture in each of these countries, from producers to processors to marketing. Scientific research is indeed critical, but no more so than ongoing improvements in on-farm practices. As an example, the work of GD - Animal Health Service, Deventer in the Netherlands is under ongoing review, with the aim to continually improve a range of industrydriven voluntary programmes in animal health, including udder health (GD - Animal Health Service, Deventer, 2006).

- Proactive planning. In these countries, improvements in animal health are underpinned by detailed planning at least five to seven years into the future. These longterm strategies are then used as the basis for policy, operations and research. Stable, long-term planning and commitment is particularly important in animal health, due to the long lead times associated with progress. For example, Norway is only now at the final stages of BVD eradication (Valle et al., 2005), after commitment from all relevant players over a 10 -year period.

- Industry-government partnerships. In each of these countries, nationally coordinated programmes of animal health are developed and implemented under either industry leadership (with government playing a support role) or as part of a genuine industry-government partnership. For example, GD-Animal Health Services, Deventer was founded by, and for, Dutch farmers in 1919, with the objective of preventing and eradicating animal diseases. This organisation, which converted to a private company in 2000 , now leads non-regulatory animal health issues in the Netherlands. In 2005, the company had a turnover of $€ 47.1$ million. Funding for this organisation is mainly derived from industry. The importance of the industry-government partnership is well-illustrated by the experiences of BTEC (Australia's brucellosis and tuberculosis eradication programme), where it has been suggested that "involvement of industry in both funding and policy development was an essential factor in achieving the outcome of the campaign"
(Radunz, 2006). Similarly, in Ireland, an industry-led partnership (the Egg Quality Assurance Scheme) is successfully leading international efforts towards control of salmonellosis and improved egg quality (Anon., 2001a). Industry and government each bring their own strengths and perspectives. For example, industry contributes immediacy towards the problem at hand, on-the-ground commitment and pragmatism, whereas government has considerable experience in the management of complex national programmes, the ability to create a legislative framework to support management efforts, ready-access to world-class scientific support and the ability to attract international recognition and kudos for efforts achieved.

- Industry funding. In any country, the question of "who will pay?" is a critical - and often contentious - issue. Among the international leaders, however, industry has emerged as a key financial contributor to animal health programmes, in all cases based on the recognition that industry is a key (and, on occasions, the only) beneficiary of disease control or prevention. In the Netherlands, almost all costs (on-farm, laboratory, etc.) associated with non-regulatory animal health programmes are covered by industry. Similarly, Australia's superior animal health status would never have been achieved without a significant pool of funds collected from industry through a transparent and equitable system of levies. The funding mix varies according to the programme, with government contributing a higher percentage when there is clear evidence of 'public good' (that is, benefit to the broader society, rather than solely to industry) associated with effective disease control or eradication. Industry levies provide the basis of support for a range of industry organisations, including Meat and Livestock Australia and Dairy Australia. In Australia, government automatically matches industry funds one-to-one for research-related activities.

- Industry structures. In an environment of intense global competition, it is critical that industry is focused and proactive, yet also able to react rapidly to changing international issues and opportunities. In northern Europe and Australasia, industries have undergone substantial consolidation and restructure, to maximise the ability of their farmers to remain internationally competitive. In Sweden, for example, the dairy industry is represented by a single body (the Swedish Dairy Association), with responsibility for public opinion and dairy policy, services and advisory work, and research. In Australia, Dairy Australia fulfils a similar role.

- National/regional coordination. National coordination is critical to the success of animal health programmes in northern Europe and Australasia. In the Netherlands, Johne's disease is coordinated nationally, based on representation from industry, government and relevant service-providers. In Australia, the National Johne's Disease Control Program was also developed by all 
relevant bodies, leading to a shared position, a common goal and long-term commitment to succeed (Animal Health Australia, 2007). Although more challenging, there are some examples of success in regional disease control (spanning more than one country), including coordinated efforts by Norway, Sweden and Finland to control Gyrodactylus salaris, a damaging parasite of salmon present in waterways throughout northern Scandinavia (Brørs, 2002). Because disease pays little respect for geographic regions, coordination and cooperation between the agricultural industries of Ireland and Northern Ireland will be very important.

- Coordination of technical efforts. Animal health problems are often complex, and frequently develop following the interaction of both disease and non-disease factors. Consequently, there is often the need for both veterinary and non-veterinary input in on-farm investigations and advice. In most countries, however, cooperation between different organisations or professions is problematic, due to past experiences or differing perspectives. In Countdown Downunder, which is playing a key role in reducing mastitis problems on Australian farms, the coordinated efforts of veterinarians and non-veterinary farm advisors has proved critical to programme success.

- Excellence in technical support. The animal health challenges of today are very different from those faced 20 or more years ago. Health issues are generally more complex, and farmers and animals are generally under greater and more varied pressures. At the national level, it is critical that programmes comply with international best-practice, in terms of technical excellence. Further, there are ongoing changes to the skills-base required by veterinarians and non-veterinary farm advisors. Continuing education among veterinarians and nonveterinary farm advisors is critical, as is a transparent means to enable farmers to identify and approach those with advanced technical knowledge and experience. InCalf is an industry-funded national learning program working with Australian dairy farmers and their advisors to achieve measured improvement in herd reproductive performance. As part of a commitment to transparency in this programme, all accredited InCalf advisors are listed on the internet. A variety of innovative methods have been developed to positively support farmers to increase their technical but also generic knowledge and skills, including discussion groups and programmes which incorporate principles of adult learning (Brightling et al., 2005). In Ireland, farmer discussion groups are generally organised by Teagasc, the Irish Agriculture and Food Development Authority.

- Planned, focused and coordinated research. Research is relevant to many, but not all, on-farm or national animal health problems. In many cases, relevant (although perhaps not complete) information is already available. A feature of the leading animal health programmes has been an ongoing and critical evaluation of the issues, specifically to identify those questions which - if answered - would significantly increase the likelihood of disease control (or eradication). In other words, research can play a critical role in maximising programme success, particularly if it is planned, focused and coordinated. The Dutch are leading international efforts towards control of Johne's disease specifically because national control efforts are being supported by a planned, highly-focused and technically excellent programme of research.

- Information for improved decision-making. Objective and timely information is a prerequisite to informed decisionmaking in all business endeavours, including farming. In a number of countries, farmers now have access to detailed information about the performance of their herd, including the facility to benchmark the performance of their herd against that of equivalent herds in the region or nationally. For example, such a facility is now available to Norwegian dairy farmers, through the efforts of the Norwegian Cattle Health Service. A similar system is in development in Ireland, through the work of the Irish Cattle Breeders Federation. In a similar manner, regional and national animal health surveillance information provides industry and government with a means to prioritise resources, identify emerging problems and provide assurance (as relevant) to international buyers concerning disease freedom.

\section{In summary}

There are a range of issues associated with international best-practice in animal health, including the following:

- A focus on continuous improvement

- Proactive planning

- Industry-government partnerships

- Industry funding

- Industry structures

- National coordination

- Coordination of technical efforts

- Excellence in technical support

- Planned, focused and coordinated research

- Information for improved decision-making

\section{The herd health initiative}

There is broad acceptance of the need for Ireland to achieve international best-practice in key areas of animal health. As yet, however, little progress has been made towards this goal.

The herd health initiative (HHI) has been proposed as a means to enable Ireland to proactively improve the animal health status of the national herd. Essentially, it is based on the ideas suggested here. The basic concept is that industry and government come together to form a not-forprofit organisation which, following establishment, would proactively provide focus, leadership and coordination of all non-regulatory animal health issues in Ireland. As a key outcome, the HHI would develop an integrated national approach to these animal health issues, through a cooperative 
partnership between all relevant stakeholders, and a focus on on-farm profitability and, at the national level, market access and international competitiveness.

Given the stakes involved, it would seem unwise for 'Ireland Inc.' not to seriously consider the issues raised here. Based on experiences of animal health from northern Europe and Australasia, there is little doubt that Ireland will be able to shape its own future in a global trading environment, should it choose to do so. There is strong support for the HHI (or a suitable alternative model) in government, in some sectors of industry and among service providers. At the end of the day, however, it is entirely up to industry whether it is able and willing to meet this challenge.

\section{References}

Animal Health Australia (2007). National Johne's Disease Control Program (NJDCP). http://www.animalhealthaustralia.com.au/aahc/programs/jd/ njdcp.cfm. Accessed on 31 July, 2007.

Anon. (2001a). Egg quality assurance standard, Revision 2, April 2001. Bord Bia, Dublin.

Anon. (2001b). Countdown Downunder 1999-2001: Improving mastitis control on dairy farms. Dairy Research and Development Corporation. http://www.countdown.org.au/pdf/about_pdf/Final_Report.pdf. Accessed 31 July, 2007.

Anon. (2005a). Definition of a BoHV-1-free animal and a BoHV-1-free holding, and the procedures to verify and maintain this status. EFSA Journal 311: 1-65. http://www.efsa.europa.eu/etc/medialib/efsa/science/ahaw/ahaw_ opinions/1348.Par.0001.File.dat/ahaw_ibr_report1.pdf. Accessed 31 July, 2007.

Anon. (2005b). Trade in agricultural goods and fishery products. EU Exports and SPS Measures Debate 2005: twenty-five stars or one circle? http:// ec.europa.eu/trade/issues/sectoral/agri_fish/sps/seminar_en.htm. Accessed 31 July, 2007.

Anon. (2006a). Ireland ranked second in global wealth table. RTE News, 10 July, 2006. http://www.rte.ie/news/2006/0710/economy.html. Accessed on 31 July, 2007

Anon. (2006b). The world's most expensive cities in 2006. http://www. citymayors.com/economics/expensive_cities2.html. Accessed on 31 July, 2007. Bassett, H.F., Monaghan, M.L., Lenhan, P., Doherty, M.L. and Carter, M.E. (1990). Bovine digital dermatitis. Veterinary Record 126: 164-165. Berry, D.P., O'Brien, B., O'Callaghan, E.J., O'Sullivan, K. and Meaney, W.J. (2006). Temporal trends in bulk tank somatic cell count and total bacterial count in Irish dairy herds during the past decade. Journal of Dairy Science 89: 4083-4093.

Brightling, P., Hope, A., Thompson, A. and Dyson, R. (2005) Countdown Downunder 2001-2004: Building industry capacity to control mastitis and manage milk quality. Dairy Australia. http://www.countdown.org.au/pdf/ about_pdf/Countdown_Report_2005.pdf. Accessed 31 July, 2007.

Brørs, S. (ed.) (2002). The salmon parasite Gyrodactylus salaris on the North Calotte: suggestions for further surveillance, information, management and legislation. The North Calotte Council, Report No. 57. http://www. nordkalottradet.nu/rapport\%20nr\%2057.pdf. Accessed 31 July, 2007. Fischer Boel, M. (2006a). European agricultural policy in a changing environment. Europa Lecture, Wellington, 6 March, 2006. http://ec.europa. eu/commission_barroso/fischer-boel/speeches/archive_en.htm. Accessed 31 July, 2007.

Fischer Boel, M. (2006b). The future of agriculture in Ireland. Dublin, 10 May, 2006. http://ec.europa.eu/commission_barroso/fischer-boel/speeches/ archive_en.htm. Accessed 31 July, 2007.

GD - Animal Health Service Deventer (2006). The GD update 2 - 2006 http://www.gddeventer.com/. Accessed 31 July, 2007.

Griffin, J.M., Williams, D.H., Kelly, G.E., Clegg, T.A., O’Boyle, I., Collins, J.D. and More, S.J. (2005). The impact of badger removal on the control of tuberculosis in cattle herds in Ireland. Preventive Veterinary Medicine 67:
237-266

Healy, A.M., Farmer, M.L. and Doherty, M.L. (1996). Arthritis due to Mycoplasma bovis in a homebred Charolais calf. Irish Veterinary Journal 49: 527-528.

International Trade Centre UNCTAD/WTO (2005). International Trade Statistics 2001-2005. http://www.intracen.org/tradstat/welcome.htm.

Accessed 31 July, 2007.

Kennedy, J. (2006). The somatic cell count blame game. Irish Farmers Journal, 26 August, 2006. http://www.farmersjournal.ie/2006/0826/farmmanagement/ dairy/feature.shtml. Accessed 31 July, 2007.

Lindberg, A., Brownlie, J., Gunn, G.J., Houe, H., Moennig, V., Saatkamp, H.W., Sandvik, T. and Valle, P.S. (2006). The control of bovine viral diarrhoea virus in Europe: today and in the future. Revue scientifique et technique - Office International des Epizooties 25: 961-979.

More, S.J. and Good, M. (2006). The tuberculosis eradication programme in Ireland: a review of scientific and policy advances since 1988. Veterinary Microbiology 112: 239-251.

Nishi, J.S., Shury, T. and Elkin, B.T. (2006). Wildlife reservoirs for bovine tuberculosis (Mycobacterium bovis) in Canada: Strategies for management and research. Veterinary Microbiology 112: 325-328.

O'Brien, D.J. Schmitt, S.M., Fitzgerald, S.D., Berry, D.E. and Hickling, G.J. (2006). Managing the wildlife reservoir of Mycobacterium bovis: The Michigan, USA, experience. Veterinary Microbiology 112: 313-323.

O'Doherty, S., Prendergast, M., Scanlon, M., Schofield, W.L., Doherty, M.L., Frame, M. and Bassett, H.F. (2000). Corynebacterium pseudotuberculosis in an imported ewe. Irish Veterinary Journal 53: 631-634.

Pokorova, D. Vesely, T., Piackova, V., Reschova, S. and Hulova, J. (2005).

Current knowledge on koi herpesvirus (KHV): a review. Veterinární

Medicína 50: 139-147.

Radunz, B. (2006). Surveillance and risk management during the latter stages of eradication: Experiences from Australia. Veterinary Microbiology 112: 283-290.

Reviriego Gordejo, F.J. and Vermeersch, J.P. (2006). Towards eradication of bovine tuberculosis in the European Union. Veterinary Microbiology 112: 101-109.

Reynolds, D. (2006). A review of tuberculosis science and policy in Great Britain. Veterinary Microbiology 112: 119-126.

Ryan, T.J., Livingstone, P.G., Ramsey, D.S.L., de Lisle, G.W., Nugent, G., Collins D.M. and Buddle, B.M. (2006). Advances in understanding disease epidemiology and implications for control and eradication of tuberculosis in livestock: The experience from New Zealand. Veterinary Microbiology 112: 211-219.

Thornberry, H. (1976). Warble fly in Ireland. Irish Veterinary Journal 30: 83-88. Valle, P.S., Skjerve, E., Martin, S.W., Larssen, R.B., Østerås, O. and Nyberg, O. (2005). Ten years of bovine viral diarrhoea virus (BVDV) control in Norway: a cost-benefit analysis. Preventive Veterinary Medicine 72: 189-207. World Trade Organization (2007). Sanitary and Phytosanitary Measures. http://www.wto.org/english/tratop_e/sps_e/sps_e.htm. Accessed on 31 July, 2007.

\section{Relevant websites}

From Australia

Countdown Downunder, www.countdown.com.au

Dairy Australia, www.dairyaustralia.com.au

InCalf, www.incalf.com.au

Meat and Livestock Australia, www.mla.com.au

From Ireland

Teagasc, www.teagasc.ie

The Irish Cattle Breeders Federation, www.icbf.com

From the Netherlands

GD - Animal Health Service, Deventer, www.gddeventer.com

From Norway

Norwegian Cattle Health Service, http://storfehelse.tine.no/engelsk/doku-

menter.cfm? kat $=35$

From Sweden

The Swedish Dairy Association, www.svenskmjolk.se 